\title{
Impact of climate change on coastal versus estuarine nursery areas: cellular and whole-animal indicators in juvenile seabass Dicentrarchus labrax
}

\author{
Catarina Vinagre ${ }^{1, *}$, Diana Madeira ${ }^{1}$, Luís Narciso $^{2}$, Henrique N. Cabral $^{1}$, \\ Mário S. Diniz ${ }^{3}$ \\ ${ }^{1}$ Universidade de Lisboa, Faculdade de Ciências, Centro de Oceanografia, Campo Grande, 1749-016 Lisboa, Portugal \\ ${ }^{2}$ Universidade de Lisboa, Faculdade de Ciências, Centro de Oceanografia, Laboratório Marítimo da Guia, \\ Avenida Nossa Senhora do Cabo, 939, 2750-374 Cascais, Portugal \\ ${ }^{3}$ Requimte, Departamento de Química, Centro De Química Fina e Biotecnologia, Faculdade de Ciências e Tecnologia, \\ Universidade Nova de Lisboa, 2829-516 Caparica, Portugal
}

\begin{abstract}
The effects of thermal conditions of coastal and estuarine nurseries, both in the present and in the near future, on juvenile fish were compared. The response of the European seabass Dicentrarchus labrax was investigated through a long-term experiment in captivity, where 0-group juveniles were exposed to temperatures that reflect the average summer temperature that they encounter in coastal $\left(18^{\circ} \mathrm{C}\right)$ and estuarine nurseries $\left(24^{\circ} \mathrm{C}\right)$, and also the temperature that they endure inside estuaries during heat waves $\left(28^{\circ} \mathrm{C}\right)$. The combined expression of 2 heat shock proteins (Hsc/Hsp70) in white muscle was assessed throughout a long-term experiment $(30 \mathrm{~d})$. Growth and condition were determined at the end of the experiment. Hsc/Hsp70 levels were constant throughout the first $15 \mathrm{~d}$ at $18^{\circ} \mathrm{C}$, and then decreased steeply. At 24 and $28^{\circ} \mathrm{C}$, Hsc/Hsp70 levels increased considerably after $15 \mathrm{~d}$, particularly at $28^{\circ} \mathrm{C}$, and decreased at the end of the experiment. Daily growth was $0.20 \mathrm{~mm} \mathrm{~d}^{-1}$ at $18^{\circ} \mathrm{C}$, it increased to $0.34 \mathrm{~mm} \mathrm{~d}^{-1}$ at $24^{\circ} \mathrm{C}$, and was lowest at $28^{\circ} \mathrm{C}$, at $0.16 \mathrm{~mm} \mathrm{~d}^{-1}$. Condition, assessed by Fulton's $K$, was 0.95 at $18^{\circ} \mathrm{C}, 1.00$ at $24^{\circ} \mathrm{C}$ and 0.83 at $28^{\circ} \mathrm{C}$. The Hsc/Hsp70 increase at 24 and $28^{\circ} \mathrm{C}$ is an indication that molecular reparation processes were underway. The peak growth and condition values registered at $24^{\circ} \mathrm{C}$ suggest that estuarine average summer temperatures are more beneficial for this species' juveniles than coastal temperatures. Acclimation was observed at $24^{\circ} \mathrm{C}$, yet growth rates and condition values indicate that prolonged heat waves $\left(28^{\circ} \mathrm{C}\right)$ may result in lower fitness.
\end{abstract}

KEY WORDS: Climate change - Hsc/Hsp70 - Heat stress · Thermal tolerance · Heat acclimatization $\cdot$ Molecular chaperone $\cdot$ Growth

\section{INTRODUCTION}

Elevated water temperature is generally considered one of the most problematic stressors that will affect fish as a result of climate change. As temperature increases, metabolic rate, heart rate, gastric evacuation and growth increase linearly but only until the optimal temperature is reached (Pörtner
2002). If temperature is increased above the species optimum, the available energy for other activities decreases because of a temperature-dependent reduction of the active metabolic rate (Iwama et al. 2004).

Maintenance of homeostasis occurs at several levels: cell, tissue and systemic. At the cell level, the production of heat shock proteins (HSPs) is an important mechanism in the heat shock response (Iwama 
et al. 2004). HSPs are ubiquitous and evolutionally highly conserved, occurring in all organisms from bacteria and yeast to fish and humans (Feder \& Hofmann 1999). The Hsc/Hsp70 family of proteins is the most temperature sensitive of the heat shock response. They are thought to have a molecular chaperone function that prevents intramolecular and intermolecular interactions that can result in the misfolding or aggregation of proteins (Welch \& Feramisco 1985). The chaperone functions of Hsp70 appear to be closely related to stress tolerance in animal cells, and overexpression of Hsp70 enhances antiapoptotic activity (Mosser et al. 1997).

The analysis of HSPs has been used in ecology as a biochemical indicator for the degree of protein unfolding that a cell is experiencing and an indirect measure of protein damage (e.g. Viant et al. 2003, Hofmann 2005). However, a complete understanding of the mechanisms underlying the regulation of HSPs is far from clear (Iwama et al. 2004), particularly in what concerns the effects of chronic stress. The integrated assessment of whole-animal indicators, such as growth and condition, along with HSPs in fish under chronic thermal stress can be used to concomitantly evaluate cellular stress and general fitness, allowing important insights into processes of thermotolerance and acclimatization, as well as the detrimental effects at the whole-animal level. However, such studies have not been carried out for juvenile marine fish.

The juveniles of coastal fish species often use coastal and estuarine areas as nurseries where they spend their first year of life (Haedrich 1983). Along with food availability, one of the main reasons why juveniles concentrate in these areas is their warm temperatures, which are favourable to rapid development (Haedrich 1983). However, the temperature range found in estuarine nurseries is generally considerably higher than that found in coastal nurseries (Poxton \& Allouse 1982). Several marine fish juveniles use both coastal and estuarine nurseries, yet the effect of the differential temperature over the juveniles' fitness is generally untested.

It is accepted that the higher temperatures attained by the estuarine waters will enable faster growth rates; however, heat waves are predicted to become more frequent and prolonged (IPCC 2001), which may lead to estuarine water temperatures above the optimum thermal interval of some fish species, with concomitant negative effects on cellular stress, growth and general fitness. Other factors may also be at play, such as food availability and salinity. This is why the effect of temperature should be investigated in experimental studies performed in captivity, which are lacking for the 0-group juveniles of marine fish species.

The European seabass Dicentrarchus labrax is one of the marine species whose juveniles use both coastal and estuarine nurseries. This is a highly valued fish whose distribution extends from North Africa to Norway, including the Mediterranean and the Black Sea (Smith 1990). Adults migrate to coastal areas during the spawning season; larvae develop near the coast and then migrate to sheltered coastal or estuarine nurseries where they spend their first years of life (Holden \& Williams 1974). The investigation of the effect of temperature on this species' 0 -group juveniles is particularly important in its southern range where temperatures are higher and more likely to be over the optimum thermal interval. The optimum thermal interval for this species' adults has been reported as being 20 to $25^{\circ} \mathrm{C}$ (Claireaux \& Lagardère 1999). Dicentrarchus labrax are highly eurythermic and adults can occur in water colder than $5^{\circ} \mathrm{C}$, although they show a preference for temperatures above $10^{\circ} \mathrm{C}$ and can withstand temperatures as high as $32^{\circ} \mathrm{C}$ (Pickett \& Pawson 1994). Madeira et al. (2012) recently reported that this species' critical thermal maximum is $33.3^{\circ} \mathrm{C}$.

The present work aimed to investigate and compare the combined expression of Hsc/Hsp70, growth and condition in 0-group juveniles of Dicentrarchus labrax at different temperatures, reflecting the average summer temperature that juveniles of this species encounter in coastal $\left(18^{\circ} \mathrm{C}\right)$ and estuarine nurseries $\left(24^{\circ} \mathrm{C}\right)$ along the Portuguese coast, as well as the temperature that they endure inside estuaries during heat wave events $\left(28^{\circ} \mathrm{C}\right)$. This is the first time that Hsc/Hsp70 and whole-animal fitness indicators have been simultaneously investigated in a long-term thermal stress experiment with 0 -group fish. The proteins analysed were 73-kDa constitutive heat shock cognate protein (Hsc70) and stress-inducible72-kDa heat shock protein (Hsp70) (referred to collectively as Hsc/Hsp70).

\section{MATERIALS AND METHODS}

Juvenile Dicentrarchus labrax (mass range: 4.6 to $7.5 \mathrm{~g}$; total length range: 75 to $86 \mathrm{~mm}$ ) were obtained from a local hatchery (A. Coelho e Castro, Lda, Póvoa doVarzim, Portugal) that uses local progenitors. Water is taken directly from the environment, with no heating. Upon arrival at the laboratory the fish were kept in 3 indoor re-circulating water systems, each comprising four $70 \mathrm{l}$ tanks, in a total of 12 tanks, 
supplied with aerated seawater. The water dissolved $\mathrm{O}_{2}$ level varied between 95 and $100 \%$. The work was conducted in re-circulating water systems, so all tanks in each system had the same conditions because they are inter-connected. Also, all tanks were the same size and were exposed to similar light and temperature conditions. The number of individuals per tank was 8 (3 systems, each with 4 tanks, 8 fish per tank = total of 96 fish). Fish were allowed to acclimate for $3 \mathrm{wk}$ at $16^{\circ} \mathrm{C}$, the same temperature found in the hatchery upon collection. They were fed twice a day with commercial dry food ad libitum. After $3 \mathrm{wk}$, temperature was raised at a rate of $1^{\circ} \mathrm{C}$ every $2 \mathrm{~h}$ until reaching the experimental temperatures of 18 , 24 and $28^{\circ} \mathrm{C}$. These temperatures were chosen to reflect: (1) the mean western Atlantic coastal water temperature (at $\left.\sim 38^{\circ} \mathrm{N}\right)$ in summer $\left(18^{\circ} \mathrm{C}\right)$, (2) the mean summer estuarine water temperature $\left(24^{\circ} \mathrm{C}\right)$ (Centro de Oceanografia Database) and (3) the water temperature registered during summer heat waves in Portuguese estuarine nurseries $\left(28^{\circ} \mathrm{C}\right.$ ) (Centro de Oceanografia Database).

Fish were kept at the experimental temperatures for $30 \mathrm{~d}$. To study individual growth each fish was tagged with an external numbered fine T-bar anchor tag (Hallprint). Fish were measured at the beginning of the experiment and on the last day (to the nearest $0.1 \mathrm{~mm}$ ). Growth increment was registered and divided by $30 \mathrm{~d}$ to estimate daily growth rate.

At the end of the experiment fish mass (wet mass, measured to the nearest $0.01 \mathrm{~g}$ ) was measured to calculate Fulton's $K$, a condition factor, which was directly determined from the morphometric data with the formula:

$$
K=100 M_{\mathrm{t}} / L_{\mathrm{t}}^{3}
$$

where $M_{\mathrm{t}}$ is total wet mass (mg) and $L_{\mathrm{t}}$ is total length (mm) (Ricker 1975).

At $t=0,15$, and $30 \mathrm{~d}, 3$ fish were randomly sampled at each temperature and killed by cervical transection following the European Food Safety Authority recommendations. Samples of dorsal white muscle were excised, immediately frozen in liquid nitrogen and stored at $-20^{\circ} \mathrm{C}$. The total number of muscle samples was 27 (3 replicates, 3 times, 3 temperatures).

\section{Hsc/Hsp70 extraction and quantification}

Muscle samples were processed in cold buffer solution (sodium phosphate buffer solution, $\mathrm{pH}$ 7.4) to extract the cytosolic Hsc/Hsp70 proteins, using a glass/teflon Potter Elvejhem tissue grinder. The samples were then centrifuged for $5 \mathrm{~min}$ at 16000 $\times g$. The supernatant of the homogenate was removed to a new Eppendorf tube and frozen immediately to await further analysis. Fish samples were diluted 1:200 in carbonate-bicarbonate buffer (Sigma-Aldrich C-3041). Hsc/Hsp70 proteins were quantified by ELISA (Njemini et al. 2005) using 96well microplates (Nunc-Roskilde). Three replicates of $50 \mu \mathrm{l}$ were taken from each diluted sample and transferred to the microplate wells. Following an incubation period overnight at $4{ }^{\circ} \mathrm{C}$, the microplate was washed in PBS $0.05 \%$ Tween-20 and $200 \mu \mathrm{l}$ of $1 \%$ bovine serum albumin (BSA) blocking solution was added to each well. The microplate was left in the incubator at $37^{\circ} \mathrm{C}$ for $1 \mathrm{~h} 30 \mathrm{~min}$ and washed again as described previously. Then, the primary antibody (anti-Hsc/Hsp70, Acris) detecting 72 and 73 kDa proteins corresponding to the molecular mass of inducible hsp70 and hsc70 was diluted to $0.5 \mu \mathrm{g} \mathrm{ml}^{-1}$ in $1 \%$ BSA solution and loaded in each well (50 $\mu \mathrm{l}$ each). The microplate was incubated for another $1 \mathrm{~h}$ 30 min and then washed. Secondary antibody (antimouse IgC-fab specific, alkaline phosphatase conjugate, Sigma-Aldrich) was diluted to $1 \mu \mathrm{g} \mathrm{ml}^{-1}$ in $1 \%$ BSA solution and added to the microplated wells. After incubating for $1 \mathrm{~h} 30 \mathrm{~min}$, the microplate wells were washed and $100 \mu$ l of substrate (SIGMAFAST ${ }^{\mathrm{TM}}$ p-nitrophenyl phosphate, Sigma-Aldrich) was added to each well and incubated for $30 \mathrm{~min}$ at room temperature. Then $50 \mu$ of stop solution (3 N NaOH) were added and absorbance was read at $405 \mathrm{~nm}$ in a microplate reader (Bio-Rad, Benchmark). The total protein in samples was calculated following the Bradford method (Bradford 1976) and expressed as micrograms of total protein.

\section{Statistical tests}

A 2-way ANOVA was performed to test for the effect of sampling time and temperature on Hsp70 values, after the data were tested for normality and homocedasticity. This analysis was followed by Tukey's post hoc tests whenever the null hypothesis was rejected. ANOVAs were performed to test for the effect of temperature on growth and condition, followed by Tukey's post hoc tests whenever the null hypothesis was rejected. A significance level of 0.05 was used in all test procedures. All statistics were performed using the software Statistica (Version 9.0, StatSoft). Tank effect was not included in the statistical analysis because preliminary investigations showed that it was not significant. 


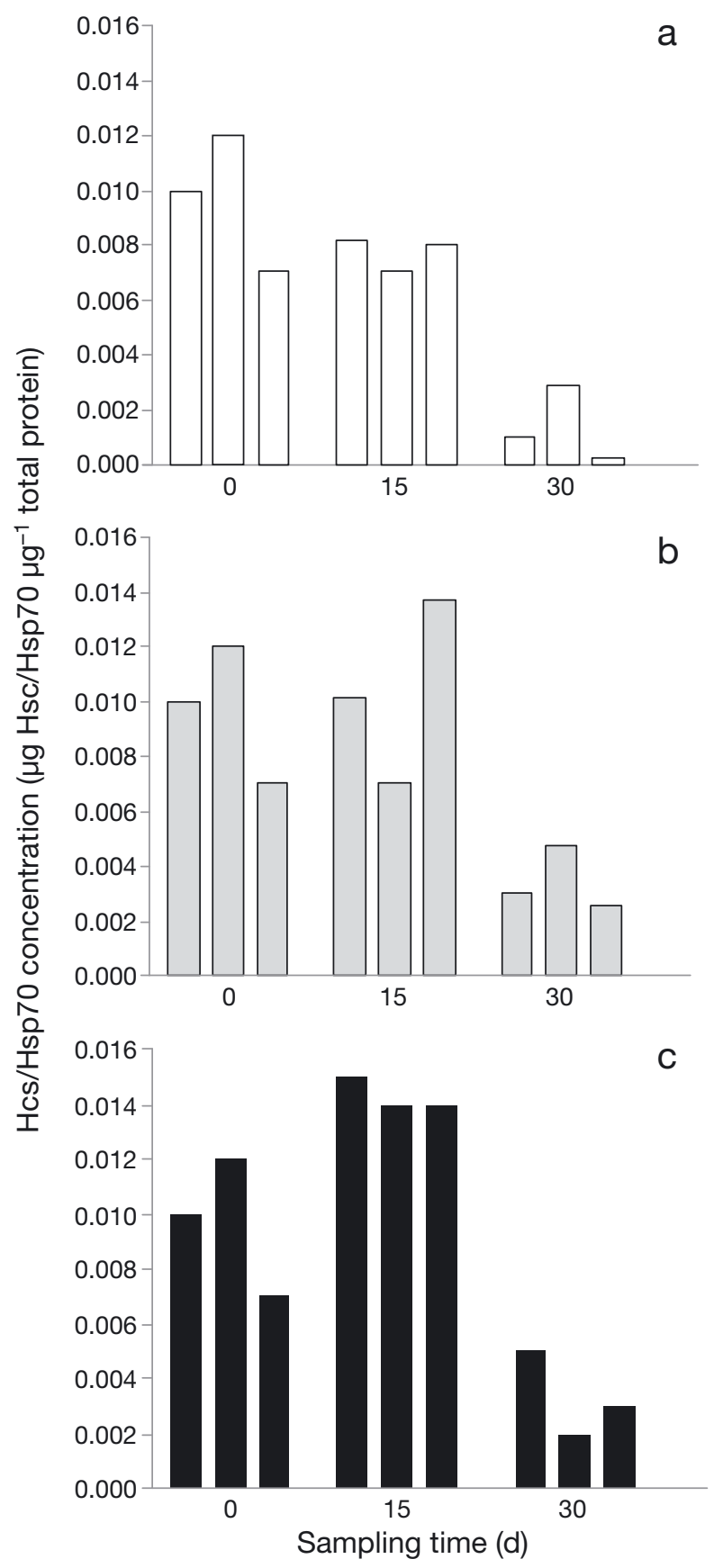

Fig. 1. Hsc/Hsp70 ( $\mu \mathrm{g} \mathrm{Hsc/Hsp70} \mu^{-1}$ total protein) levels throughout the duration of the experiment $(30 \mathrm{~d})$ at (a) $18^{\circ} \mathrm{C}$, (b) $24^{\circ} \mathrm{C}$ and (c) $28^{\circ} \mathrm{C}$ (bars represent each individual)

\section{RESULTS}

Hsc/Hsp70 concentration in the white muscle of Dicentrarchus labrax was significantly affected by sampling time and temperature (Fig. 1, Table 1). The production patterns throughout time were different according to the tested temperatures (Fig. 1). At $18^{\circ} \mathrm{C}$, Hsp70 levels were stable after $15 \mathrm{~d}$ compared
Table 1. Two-way ANOVA results for Hsc/Hsp70 ( $\mu \mathrm{g} \mathrm{Hsc/}$ Hsp70 $\mu^{-1}$ total protein) accounting for temperature and sampling time (significant values are in bold)

\begin{tabular}{|lrrr|}
\hline & df & \multicolumn{1}{c|}{$F$} & \multicolumn{1}{c|}{ p } \\
\hline Temperature & 2 & 379.90 & $\mathbf{< 0 . 0 5}$ \\
Time & 2 & 4.86 & $<\mathbf{0 . 0 5}$ \\
Temperature $\times$ Time & 2 & 42.77 & 0.17 \\
\hline
\end{tabular}

with the initial level. At $24^{\circ} \mathrm{C}$, there was a considerable increase in Hsc/Hsp70 levels after $15 \mathrm{~d}$, and at $28^{\circ} \mathrm{C}$ this increase was even higher. After $30 \mathrm{~d}$, Hsc/Hsp70 levels decreased at all temperatures to considerably lower values (Fig. 1). Post hoc tests only showed differences in Hsc/Hsp70 levels between $t=$ $0 \mathrm{~d}$ and $t=30 \mathrm{~d}$ and between $t=15 \mathrm{~d}$ and $t=30 \mathrm{~d}$.

Temperature significantly affected growth of $\mathrm{Di}$ centrarchus labrax (Table 2). Growth was $0.20 \mathrm{~mm}$ $\mathrm{d}^{-1}(\mathrm{SD}=0.03)$ at $18^{\circ} \mathrm{C}_{i}$ it increased to $0.34 \mathrm{~mm} \mathrm{~d}^{-1}$ $(\mathrm{SD}=0.07)$ at $24^{\circ} \mathrm{C}$ and decreased to $0.16 \mathrm{~mm} \mathrm{~d}^{-1}$ (SD $=0.04$ ) at $28^{\circ} \mathrm{C}$ (Fig. 2). Post hoc tests showed that growth was significantly different among all temperatures $(\mathrm{p}<0.05)$.

Condition of Dicentrarchus labrax was also significantly affected by temperature (Table 2). Fulton's $K$ was $0.99(\mathrm{SD}=0.07)$ at $18^{\circ} \mathrm{C}, 1.00(\mathrm{SD}=0.06)$ at $24^{\circ} \mathrm{C}$ and $0.89(\mathrm{SD}=0.04)$ at $28^{\circ} \mathrm{C}$, to (Fig. 3). Post hoc tests showed that condition was significantly different between 18 and $28^{\circ} \mathrm{C}$, and 24 and $28^{\circ} \mathrm{C}(\mathrm{p}<0.05)$.

\section{DISCUSSION}

The exposure of 0-group Dicentrarchus labrax to 18,24 and $28^{\circ} \mathrm{C}$ in this long-term experiment showed that the induction of Hsc/Hsp70 was higher at the highest temperature tested. Our results indicate that this species' juveniles face thermal stress at 24 and $28^{\circ} \mathrm{C}$ because the peak in $\mathrm{Hsc} / \mathrm{Hsp} 70$ shows that molecular repair processes were underway (Kregel 2002). The much higher peak in $\mathrm{Hsc} / \mathrm{Hsp} 70$ at $28^{\circ} \mathrm{C}$ is indicative that this temperature elicits higher stress and thus higher demands in molecular repair.

The ability of HSP families to confer thermotolerance in animals is well documented (Kregel 2002, Viant et al. 2003). Thermotolerance refers to the ability of the organism to survive heat stress and is characterized by elevated cellular HSPs (Moseley 1997). This adaptation has a relatively short duration (hours to days) and is correlated with the high concentrations of HSPs in the cells. Thermotolerance undergoes a rapid decay that correlates with the decline in 
Table 2. ANOVAs results for growth $\left(\mathrm{mm} \mathrm{d}^{-1}\right)$ and condition $(K)$ of Dicentrarchus labrax registered at 18,24 and $28^{\circ} \mathrm{C}$ (significant values are in bold)

\begin{tabular}{|lrrc|}
\hline & df & $F$ & $p$ \\
\hline Growth & 2 & 30.82 & $\mathbf{< 0 . 0 5}$ \\
Condition & 2 & 6.20 & $<\mathbf{0 . 0 5}$ \\
\hline
\end{tabular}

HSPs (Moseley 1997, Kregel 2002). This process was observed in the present experiment, where Hsc/Hsp70 peaks were not maintained long-term and were followed by a steep decline at the end of the experiment.

In contrast to thermotolerance, which is a shortlived process, heat acclimation is indefinite, as long as the individual continues to be exposed to periodic elevations in temperature (Moseley 1997). A growing body of literature shows that Hsp70 is also involved in the process of heat acclimation (e.g. Moseley 1997, Hofmann 2005). Various studies have shown that ecthoterms such as lizards present higher constitutive Hsp70 levels according to the environmental niche they occupy (Ulmasov et al. 1992).

Heat acclimation was not observed in the present study at $28^{\circ} \mathrm{C}$, the temperature attained in estuarine nurseries during heat waves. At this temperature, Dicentrarchus labrax juveniles present low levels of Hsp70, slightly lower condition and an important decline in growth, which indicates that prolonged heat waves are detrimental for juveniles that occur in estuarine areas. In addition, Vinagre et al. (2012) found increased levels of oxidative stress in this species at $28^{\circ} \mathrm{C}$, which are also indicative of cellular damage and reparation processes.

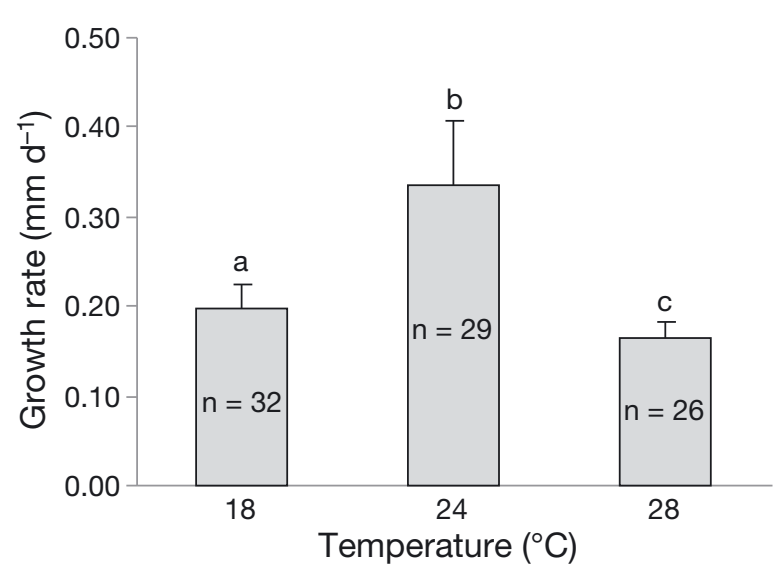

Fig. 2. Growth rates of Dicentrarchus labrax at 18, 24 and $28^{\circ} \mathrm{C}$ (significantly different values are marked with different letters)
Although the primary response of fish to stress is characterized by the rapid release of stress hormones, e.g. catecolamines and cortisol, into the circulatory system (Gamperl et al. 1994) and the secondary response comprises a wide range of changes in the blood, organs and tissues (Vijayan et al. 1994, Barton et al. 2002), which includes HSP production, the tertiary response occurs at the whole-animal and population levels. If fish are unable to acclimate, wholeanimal changes will occur, with the repartitioning of energy caused by the increase energetic demands associated with stress (Iwama et al. 2004). Thus chronic exposure to stressors can lead to decreases in growth, disease resistance, swimming performance, etc. (Iwama et al. 2004). The growth arrest observed in Dicentrarchus labrax at $28^{\circ} \mathrm{C}$ appears consistent with a tertiary response to chronic stress at the whole-animal level. At a population level, the effects of chronic stress may result in lower recruitment, lower survival and a decline in the adult stocks.

At $24^{\circ} \mathrm{C}$, growth was high, as was condition, and although Hsp70 levels were low at the end of the experiment, we must conclude that there was acclimation to this temperature, because no detrimental effects could be observed at the whole-animal level. The peak growth and condition values registered at $24^{\circ} \mathrm{C}$ indicate that the average summer temperatures registered in estuarine nurseries are more beneficial for this species' 0-group juveniles than coastal average summer temperatures $\left(18^{\circ} \mathrm{C}\right)$. A similar pattern of $\mathrm{Hsp} 70$ production was reported for steelhead trout Oncorhynchus mykiss at $20^{\circ} \mathrm{C}$. Hsp 70 induction was strong during the first days and then dropped to very low values, with no effect on growth, suggesting acclimation (Viant et al. 2003).

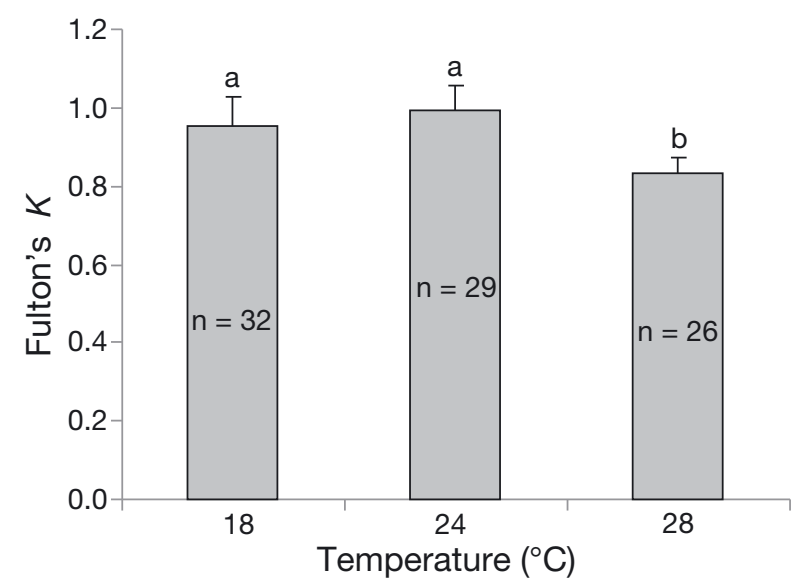

Fig. 3. Condition of Dicentrarchus labrax at 18,24 and $28^{\circ} \mathrm{C}$ (significantly different values are marked with different letters) 
Other authors have shown that temperatures between 20 and $25^{\circ} \mathrm{C}$ encompass the thermal optimum for Dicentrarchus labrax. Claireaux \& Lagardère (1999) observed that in this thermal interval the metabolism of $D$. labrax becomes less susceptible to temperature fluctuations, allowing complete thermal compensation in metabolism (Precht et al. 1955). Claireaux \& Lagardère (1999) and Claireaux \& Lefrançois (2007) also concluded that homeostasis was reached at $25^{\circ} \mathrm{C}$, as at this temperature only small changes in fish metabolic capacity were observed.

Person-Le Ruyet et al. (2004) observed an arrest in growth at $29^{\circ} \mathrm{C}$ and concluded that $26^{\circ} \mathrm{C}$ is the temperature for maximal growth for 20-mo-old (82 $\mathrm{g}$ ) Dicentrarchus labrax in the range from 13 to $29^{\circ} \mathrm{C}$, which is in accordance with the results from the present study. These authors also report an increase of $8 \%$ in metabolic rate from 25 to $29^{\circ} \mathrm{C}$ related to maintenance costs due to thermal stress.

In Portugal, Dicentrarchus labrax juveniles concentrate in coastal and estuarine areas. On the coast they are exposed to temperatures of approximately $18^{\circ} \mathrm{C}$ during summer, whereas in an estuary such as the Tagus estuary, the average summer temperature is $24^{\circ} \mathrm{C}$. This means that juvenile sea bass are well within their thermal optimum in both environments at this latitude. However, estuarine waters in the Tagus estuary reach $28^{\circ} \mathrm{C}$ during heat waves (atmospheric temperature can surpass $40^{\circ} \mathrm{C}$ ), not only in the shallows but also in the main channel, where we sample sea bass juveniles for ecology studies. Because this is a well-mixed estuary, there is no thermal refuge in these areas. From the 2000s onwards, we have observed estuarine water temperatures of $28^{\circ} \mathrm{C}$ for periods of more than $2 \mathrm{wk}$, which led to the design of this $30 \mathrm{~d}$ experiment, as heat waves are expected to be more prolonged and frequent in the future. Our experiment indicates that at this temperature the juveniles of sea bass face thermal stress.

Shallow estuarine habitats that reach high temperatures are also the most productive in terms of prey and thus are traditionally regarded as excellent nursery areas. However, they will be hard hit by climate change in some parts of the world, such as southern Europe (IPCC 2001). Alterations in various abiotic parameters will occur in synergy, leading to even higher temperatures: not only are shallow habitats more prone to high temperatures because of high surface/volume ratio and low thermal inertia, but river flow will also decline because of more severe droughts (IPCC 2001). For some highly commercial species such as Dicentrarchus labrax, this may change the value of this habitat in comparison to other coastal habitats less vulnerable to climate change, as suggested by the present study.

The ability of Dicentrarchus labrax juveniles to continue to thrive in estuarine nurseries may depend on how the temperature increase will take place. If water temperature increases gradually at decadal, yearly and seasonal scales, this and other fish species may be able to acclimatize to higher temperatures than they can currently tolerate. It has been suggested that the benefit of acclimatization to elevated temperatures is to prepare the animal for the possibility of a further increase in temperature (Huey et al. 1999).

Nevertheless, knowledge on the relative value of each habitat will be crucial for prioritizing management and/or conservation actions that affect fish nurseries for this and other species (Johnston et al. 2002, Vinagre et al. 2006, 2008) in a global change scenario. Information on the ability of species to tolerate short-term temperature elevations and/or acclimatize to long-term heat elevation is fundamental for the understanding of the effect of climate change upon biota.

Acknowledgements. We thank everyone involved in the maintenance of the experimental tanks. This study was supported by the Portuguese Foundation for Science and Technology (FCT) through the funding of projects and the grant SFRH/BPD/34934/2007 awarded to C.V. This work was also supported by FCT through the strategic project no. PEst-C/EQB/LA0006/2011 granted to Requimte.

\section{LITERATURE CITED}

Barton BA, Morgan JD, Vijayan MM (2002) Physiological and condition-related indicators of environmental stress in fish. In: Adams SM (ed) Biological indicators of aquatic ecosystem stress. American Fisheries Society, Bestheda, MD, p 111-148

Bradford MM (1976) A rapid and sensitive method for the quantitation of microgram quantities of protein utilizing the principle of protein-dye binding. Anal Biochem 72: $248-254$

Claireaux G, Lagardère JP (1999) Influence of temperature, oxygen and salinity on the metabolism of the European sea bass. J Sea Res 42:157-168

Claireaux G, Lefrançois C (2007) Linking environmental variability and fish performance: integration through the concept of scope for activity. Philos Trans R Soc B 362: 2031-2041

Feder ME, Hofmann GE (1999) Heat-shock proteins, molecular chaperones and the stress response: evolutionary and ecological physiology. Annu Rev Physiol 61:243-282

> Gamperl AK, Vijayan MM, Boutilier RG (1994) Experimental control of stress hormone levels in fishes: techniques and applications. Rev Fish Biol Fish 4:215-255

Haedrich RL (1983) Estuarine fishes. In: Ketchum B (ed) Ecosystems of the world 26. Estuarine and enclosed seas. 
Elsevier, Amsterdam, p 183-207

Hofmann GE (2005) Patterns of Hsp gene expression in ectothermic marine organisms on small to large biogeographic scales. Integr Comp Biol 45:247-255

Holden MJ, Williams T (1974) The biology, movements and populations dynamics of bass, Dicentrarchus labrax, in English waters. J Mar Biol Assoc UK 54:91-107

Huey RB, Berrigan D, Gilchrist GW, Herron JC (1999) Testing the adaptive significance of acclimation: a strong inference approach. Am Zool 39:323-336

IPCC (2001) Climate change 2001: the scientific basis. Contribution of Working Group I to the third assessment report of the Intergovernmental Panel on Climate Change. IPCC, Cambridge University Press, Cambridge

Iwama GK, Afonso LOB, Todgham A, Ackerman P, Nakano K (2004) Are hsps suitable for indicating stressed states in fish? J Exp Biol 207:15-19

Johnston RJ, Grigalunas TA, Opaluch JJ, Mazzotta M, Diamantedes J (2002) Valuing estuarine resource services using economic and ecological models: the Peconic Estuary system study. Coast Manag 30:47-65

Kregel KC (2002) Heat shock proteins: modifying factors in physiological stress responses and acquired thermotolerance. J Appl Physiol 92:2177-2186

Madeira D, Narciso L, Cabral H, Vinagre C (2012) Thermal tolerance and potential climate change impact in marine and estuarine organisms. J Sea Res 70:32-41

Moseley PL (1997) Heat shock proteins and heat adaptation of the whole organism. J Appl Physiol 83:1413-1417

Njemini R, Demanet C, Mets T (2005) Comparison of two ELISAs for the determination of Hsp70 in serum. J Immunol Met 306:176-182

Person-Le Ruyet J, Mahé K, Bayon N, Delliou H (2004) Effects on growth and metabolism in a Mediterranean population of European sea bass, Dicentrarchus labrax. Aquaculture 237:269-280

Pickett GD, Pawson MG (1994) Sea bass. Biology, exploitation and conservation. Chapman \& Hall, London

Pörtner HO (2002) Climate change and temperature dependent biogeography: systemic to molecular hierarchies of thermal tolerance in animals. Comp Biochem Physiol A 132:739-761

Poxton MG, Allouse SB (1982) Water quality criteria for marine fisheries. Aquac Eng 1:153-191

Editorial responsibility: John Piatt, Anchorage, Alaska, USA
Precht H, Christophersen J, Hensel J (1955) Temperatur und Leben. Springer, Berlin

Mosser DD, Caron AW, Bourget L, Denise-Larose C, Massie B (1997) Role of the human heat shock protein hsp70 in protection against stress-induced apoptosis. Mol Cell Biol 17:5317-5327

Ricker WE (1975) Computation and interpretation of biological statistics of fish populations. Bull Fish Res Board Can 191:1-382

Smith CL (1990) Moronidae. In: Quero JC, Hureau JC, Karrer C, Post A, Saldanha L (eds) Check-list of the fishes of the eastern tropical Atlantic (CLOFETA). UNESCO, Paris, p 692-694

Ulmasov KA, Shammakov S, Karaev K, Evgenyev MB (1992) Heat shock proteins amd thermoresistance in lizards. Proc Natl Acad Sci USA 89:1666-1670

> Viant MR, Werner I, Rosenblum ES, Gantner AS, Tjeerdema RS, Johnson ML (2003) Correlation between heat-shock protein induction and reduced metabolic condition in juvenile steelhead trout (Oncorhynchus mykiss) chronically exposed to elevated temperature. Fish Physiol Biochem 29:159-171

- Vijayan MM, Reddy PK, Leatherland JF, Moon TW (1994) The effects of cortisol on hepatocyte metabolism. A study using the steroid analogue RU486. Gen Comp Endocrinol 96:75-84

> Vinagre C, Fonseca V, Cabral H, Costa MJ (2006) Habitat suitability index models for the juvenile soles, Solea solea and Solea senegalensis: defining variables for management. Fish Res 82:140-149

Vinagre C, Fonseca V, Maia A, Amara R, Cabral HN (2008) Habitat specific growth rates and condition indices for the sympatric soles populations of Solea solea (Linnaeus, 1758) and S. senegalensis Kaup 1858, in the Tagus estuary, Portugal, based on otolith daily increments and RNA:DNA ratio. J Appl Ichthyology 24:163-169

> Vinagre C, Madeira D, Narciso L, Cabral H, Diniz M (2012) Effect of temperature on oxidative stress in fish: lipid peroxidation and catalase activity in the muscle of juvenile seabass, Dicentrarchus labrax. Ecol Indic 23:274-279

Welch WJ, Feramisco JR (1985) Disruption of the three cytoskeletal networks in mammalian cells does not affect transcription, translation, or protein translocation changes induced by heat shock. Mol Cell Biol 5:1571-1581

Submitted: October 10, 2011; Accepted: June 17, 2012 Proofs received from author(s): August 30, 2012 